\title{
Depression, Family Support and Hopelessness: a Correlated Study*
}

\section{Depressión, apoyo familiar y desesperanza: un estudio de correlación}

Recibido: octubre 28 de 2011 | Revisado: enero 24 de 2013 | Aceptado: agosto 24 de 2013

\author{
MAKILIM NUNES BAPTISTA** \\ AdRIANA MUNHOZ CARNEIRO*** \\ Hugo FerRari CARDOSO **** \\ Universidade São Francisco, Itatiba, Brasil
}

doi:10.11144/Javeriana.UPSY13-2.dfsh

Para citar este artículo: Nunes Baptista, M., Munhoz Carneiro, A., \& Ferrari Cardoso, H. (2014).

Depression, family support and hopelessness: A correlated study. Universitas Psychologica, 13(2), 693-702. doi:10.11144/Javeriana.UPSY13-2.dfsh

* Research paper

** Psicólogo. Doutor - Docente do Programa de PósGraduação Stricto Sensu em Psicologia da Universidade São Francisco. Comissão de Pós Graduação. Av Alexandre Rodrigues Barbosa, 45 - Centro, CEP 13251-900, Itatiba-SP/ Brasil. Telefone: (11) 4534-8040.E-mail: makilim.baptista@saofrancisco.edu.br

**** Psicologa membro do corpo de pesquisadores do Grupo de Distúrbios Afetivos- GRUDA do Departamento de Psiquiatria da Universidade de São Paulo- USP.

***** Docente do Programa de Graduação em Psicologia da Universidade Estadual Paulista -UNESP /Bauru e do Programa e Graduação das Faculdades Integradas de Jaú.

\section{A B S T R A C T}

This study aimed to verify the relationship between depression, hopelessness and family support. to this aim, were applied the Escala Baptista de Depressão-Adulto EBADEP- A, The Beck Hopelessness Scale-BHS, Inventário de Percepção de Suporte Familiar- IPSF and a sociodemographic questionnaire on a sample of 198 undergraduate of Pharmacy and Psychology courses of a particular university at São Paulo state (Brazil) with mean age of 23.44 years $(S D=6.8)$, and with a prevalence of women $(80.7 \%)$. Results showed significant and positive correlations between EBADEP- A and BHS and significant and negative correlations between EBADEP- A/ BHS and IPSF, indicating that the higher perception of family support the fewer depressive symptoms and hopelessness, agreeing with literature. Keywords

Depressive symptoms, hopelessness, family, psychological assessment.

\section{RESUMEN}

El presente estudio buscó verificar la asociación de la depresión, desesperanza y el apoyo familiar. Con este fin, se aplicó la Escala Baptista de Depressãoversión para adultos- EBADEP-A, Escala de Desesperanza de Beck, BHS, el Inventario de Percepção de Suporte Familiar - IPSF y un cuestionario socio-demográfico en una muestra de 198 estudiantes de Farmacia y Psicología en una universidad privada en el Estado de São Paulo (Brasil), con el promedio de edad de 23.44 años $(D E=6.8)$ y de las mujeres $(80.7 \%)$. Los resultados indicaron una correlación positiva y significativa entre BHS y EBADEP- A y negativa y significativa entre EBADEP- A y BHS con IPSF, lo que sugiere que cuanto mayor es la percepción del apoyo familiar, menos síntomas depresivos y la desesperanza, que muestram que los resultados son consistentes con la literatura. Palabras clave Síntomas depresivos, desesperanza, familia, evaluación psicológica. 


\section{Introduction}

Clinical depression, also called as Major Depressive Disorder or Unipolar Depression, is considered as a multifactorial mood disorder that configure as the fourth of the six leading causes of disability worldwide and if this trend continue until 2020, in numbers, these estimates a equivalent to approximately 121 million people with depressive symptoms worldwide (American Psychiatric Association [APA], 2002; World Health Organization [WHO], 2000, 2006). This way, it is important to identify risk and protetive factors (Oliveira, Fonseca \& Del Porto, 2002).

Considering risk factors it is known that the chances of an individual to develop depression during his life time vary according to gender, being women two to three times more likely to develop symptoms clinically significant (Kornstein, 1997). Santos and Kassouf (2006) based on data from the National Household Sample Survey conducted by IBGE-PNAD in 2003 with 158.098 participants from five brazilian regions between 30 and 80 years, verified that women had two to three times more depressive symptoms than men. With regard to other variables such as ethnicity, education, income or marital status, Major Depressive Disorder appears to have no direct relationship (APA, 2002).

Others risk factors that researches pointed are low self-esteem, heredity, overprotection or lack of social support, traumatic experiences occurring in childhood or adolescent (Abramson, Metalsky, \& Alloy, 1989; Kaplan, Sadock, \& Grebb, 2007; Li, DiGiuseppe, \& Froh, 2006; Lopes, Barreira, \& Pires, 2001; Oliveiraet al., 2002; Panzarella, Alloy, \& Whitehouse, 2006). It's also necessary to consider some life events, such as change of job, unemployment, birth, marriage, among others, once that they can cause physical and psychological distress, placing them as risk factors. From this script, it's possible to perform a correct understanding of depressive disorders, considering it can be associated not only with biological aspects but also to environmental and cognitive factors, which hopelessness, which appears as a symptom of depression in diagnostic manuals (APA, 2002; Mon- toya, Jiménez, Villavicencio, La Rosa, \& Abundiz, 2003; Oliveira et al., 2002; Organização Mundial da Saúde [OMS], 1993).

Hopelessness can be interpreted though Abramson's (Abramson et al., 1989) and Beck's (Beck, Rush, Shaw, \& Emery, 1982) theories that refers to the relationship of maladaptive cognitive styles and vulnerability to major depression. On Beck's theory, hopelessness is interpreting based on a negative triad that involves a negative view of itself, personal world and future (Alford, Lester, Patel, Buchanan, \& Giunta, 1995; Osnaya, Pérez, $\&$ Romo, 2005). According to Abramnson's theory, negative attributions to life events are produce by stable and global causes, when people think that it is not possible to change what happens. Although the divergence in the perception of the event - future or current, stable or global, both affirm that negative thoughts increase the chance of depressive occurrence (Abramson et al., 1989; Alloy, Abrahamson, \& Francis, 1999; Osnaya et al., 2005; Panzarella et al., 2006). In other words, individuals with negative style are more vulnerable to depressive disorder, once that they perceive and remember more often about information from stressful events that have negative consequences (Alloy et al., 1999). Some studies about this relationship are listed below.

In order to determine how cognitive styles differ between depressed and non-depressed persons, Stafford, Alloy, Abramson, and Crossfield (2006) applied in 157 undergratuated students of both genders the Cognitive Style Questionnaire (CSQ) and Dysfunctional Attitudes Scale (DAS). After, participants are divided according to scores of these instruments, responded to a structural diagnostic interview-the Modified Schedule for Affective Disorders and Schizophrenia-Lifetime (Mod-SADS-L), the DAS and the CSQ semesterly, and the Life Event Scale (LESO) and The Stress Interview (SI). Results had suggested that cognitive styles increased the perception among those who have a predisposition to depressive depression to see the situation more negatively, indicating that negative styles could explain the increased occurrences of negative answers during the depressive episode. A study on the impact of cognitive variables over a 
semester, performed by Peñate, Perestelo, Bethencourt, and Ramírez (2009) also indicated that the cognitive styles contributed significantly to the prediction of depression. Participants were 414 undergraduated students, aged between 17 and 44 years, who answered the DAS-A, BDI, BDI II, CSQ and Scale L de Disistimulo del Eysenck Personality Questionnaire.

In the same context, Fisher (2010) studied the role of positive cognitions in depression, hopelessness and suicidal ideation in 240 persons, 84 of them psychiatric patients suffering from mood and anxiety diseases. The average age of psychiatric patients was 45.54 years $(S D=12.64)$. These, $71 \%$ were female and $78 \%$ indicated that they had history and treatment of depression, $19.5 \%$ reported previous treatment for drug abuse / alcohol, 22\% had a friend who committed suicide and $15 \%$ lost a family member for having committed suicide. The other 156 were recruited as controls (not patients), with an average age of 21.84 years $(S D=6.3), 36 \%$ were male. In this group, the most part (79.5\%) answer that they had no history of depression (79.5\%), or abuse of drugs / alcohol (92.9\%), 7\% attempted suicide and $12.8 \%$ indicated having a family member who committed suicide.

For data base, the following instruments were used, Coping Attitudes Scale - CAS, BDI, BHS, BSI, Automatic Thoughts Questionnaire-Revised-ATQ-R; Life Experiences Survey-Modified MLES, and a socio-demographic questionnaire. The results showed mean differences between groups in the CAS, BDI, BHS, BSI and MLES, indicating that psychiatric patients had lower levels of coping strategies than the students $(t=4.95, p=$ $0.001)$, as higher levels of depression $(t=6.46, p=$ $0.001)$, hopelessness $(t=5.52, p=0.001)$, suicidal ideation $(t=4.24, p=0.001)$ and experiences of stress $(t=5.99, p=0.001)$.

Thus, these studies pointed to the importance of identify factors that may predispose individuals to major depressive disorder and consequently, hopelessness, because as verified, hopelessness is related to major depression and also with suicide (Abramson et al., 1989; Alford et al., 1995; Page et al., 2006). Montoya et al (2003) studied the rela- tionship between suicidal ideation and hopelessness in 78 patients who had suicidal ideation (G1) and 89 who had no suicidal ideation (G2), applying the Beck Hopelessness Scale (BHS). Was verified that $78 \%$ of patients in G1 had some level of hopelessness, against $38 \%$ of $\mathrm{G} 2$, and the risk of suicide increased in direct relation to the magnitude of the hopelessness of 4.5 times $(p=0.001)$ in those with low hopelessness and $6.1(p=0.001)$ for those with severe hopelessness.

Another important fact pointed out by these authors is that $52 \%$ of G1 hopelessness presented with emphasis on negative mental schemes about the future (cognitive factor), underestimating their ability to overcome their personal goals, evaluating their performance less than they should, $41 \%$ motivational factor, believing that they are not able to get anything, and lack of hope that the future can change the current condition and $7 \%$ focus on the affective factor, which assesses the future as more happy than the present, and feelings of confidence about the future. As this study Monjica, Sáenz, and Rey-Anacona (2009) also verified that the level of hopelessness was significantly related to increased depressive symptoms and suicidal ideation. The sample was 95 men, aged between 19 and 59, divided among at-risk group (G1) and group without suicidal ideation (G2), also applying the BDI and BHS, a scale of Suicide Risk Plutchick, indicating the influence of multifactorial development of depression and the influence of the cognitive structure for its worsening.

Opposetly to hopelessness, a risk factor for mood disorders, there are protective factors like social support, which some studies are demonstrating that they can contribute to decrease the negative perception about future and the tendency to develop depressive symptoms, especially when it relates on family context, since that family has a great importance in a healthy development (Estramiana, Luque, \& Gallo, 2010; Lincoln, Chatters, \& Taylor, 2005; Osnaya \& Pérez, 2010; Sun \& Hui, 2007). At this point the social and family support are important for the welfare of members and can mitigate the risks of health disorders (Sander, 2004). 
In this study was adopted the definition of Baptista (2007) which believes that this support can be understood as psychological characteristics between the family members, like perception of comfort, interest, affection, protection, and autonomy, which make them feel protected and cared about. Thus, this perception tends to serve as a protective buffer for person deal with adverse situations such as chronic diseases, problems at work, among other factors. Sun and Hui (2007) found that participants with suicidal ideation with hopelessness were not satisfied with this family relationship, and classified the family support received as inadequate. This research was based on a small number of participants (13 teenagers between 13 and 18 with moderate and severe suicidal ideation) however may indicate the importance that the support from the family provides.

Lincoln and colleagues (2005) conducted a study to assess the relationships between stress, social support, negative interaction and mental health. The sample was selected from the second part of the National Comorbidity Study conducted between 1990 and 1992, resulting in a total of 591 African American men and women aged between 18 and 54 years. The results indicated negative associations between social support and depression, demonstrating that the higher the social support, less depressive symptoms. A study of 971 persons, 516 females (57.8\%), mean age 16.75 years $(S D=1.4)$ applied to BHS along with a demographic questionnaire to assess the impact of these variables to increase / decrease of hopelessness and suicidal ideation. In the sample, those who lived only with one of parents or other person had higher scores on the BHS, and the chances of committing suicide when they increased in the last three months experienced situations such as being victims of humiliation $\left(\mathrm{x}^{2}=11.40 ; p=\right.$ 0.005), undergoing economic needs $\left(\mathrm{x}^{2}=13.6\right.$, $p=0.005)$ and having family problems $\left(\mathrm{x}^{2}=\right.$ $9.20, p=0.005)$, indicating the influence of family relationships in the development / protection of mental disorders (Osnaya \& Pérez, 2010).

For such results it's important considering that familiar support and depression may interact in different ways, for example, when the perception of support received is positive, may help in the recovery of individuals with depressive symptoms, or otherwise, where depressive symptoms may distort the perception of family support that this individual receives, resulting in a negative perception of the received support, damaging this relationship (Herring \& Kaslow, 2002). Consequently, it's important to study these subjects, in order to contribute for this area and the growth of researches and programs focusing protective factors for depression. The main objective of this research was verify the relationship between depression with hopelessness and family support on an undergraduated sample.

\section{Method}

\section{Sample}

Initially, took part of this study 198 undergraduated students, however, considering the criterion for analysis, was excluded those who have not answer at least $5 \%$ of each instrument. Thus, the sample was composed by 193 undergraduate of Pharmacy $(33.2 \% ; n=64)$, and Psychology $(64 \% ; n=$ 109) courses of a private university in São Paulo state (Brazil), and $10.4 \%(n=20)$ not answer this question. About the gender, had a prevalence of women $(80.3 \% ; n=155)$, and participants aged 18 to 59 years old $(M=23.55$; $S D=6.9)$, predominantly 19 years. Or further analysis they were divided in quartiles which resulted in 30.5\% between $17-19$ years old, $(29.5 \% ; n=57), 20$ to $22(27.5 \% ; n=53), 23$ to $25(16.1 \% ; n=31), 26$ or more $(21.8 \% ; n=42)$, and $5.2 \%(n=10)$ not answer this question.

With regard to marital status and place to live, $76.2 \%(n=147)$ reported being single and $73.1 \%$ $(n=141)$ live with a nuclear family. The degree of formal schooling of the family's chef was 44\% $(n=$ $85)$ incomplete university, $19.2 \%(n=37)$, complete university, $15 \%(n=29)$ complete elementary/high incomplete $14.5 \%(n=28)$ complete elementary/ incomplete middle school, and 5.2\% $(n=10)$ Illiterate/incomplete elementary. Only $2 \%$ of students did not answer this question. 
About socio-economic status, it was found that most participants are located in the status B2 (29.2\%) receiving $948.24 \$$ per month, followed by $24.7 \%$ of participants in the Class $\mathrm{C}$, receiving $527.06 \$$ per month, $19.1 \%$ in Class B1 receiving 1594.26\$13.1\% class A2, class with 2631.33 \$ in A1 with $4430.86 \$$ and three (1.5\%) in the three class D, receiving $241.07 \$$ per month, while the remainder did not meet the sufficient criteria for the analysis of socio-economic status. It was also asked to participants the number of people that reside with them. It was found that $26.9 \%$ reported living with three people, four people with 23.9\%, 18.8\% with two people, one person with $11.2 \%$ and $19.2 \%$ indicated living with five or more people.

\section{Measures}

- Identification questionnaire: developed by the authors, containing the following sections: socio-demographic data and classification of social classes, according to the criteria of Associação Nacional de Empresas de Pesquisa ([ANEP]; 2000). This questionnaire was composed of six closed questions (marital status, members that compose his/her immediate family, parental status, social status, parental education level and gender) and two open questions (age and course).

- Baptista Depression Scale -EBADEP-A (Baptista, 2012): a 45 item test based on DSMIV (APA, 2002), ICD-10 (OMS, 1993) and Cognitive (Beck et al., 1982) and Behavior (Fester, 1983) theories. EBADEP-A is a set of 26 descriptors, such as depressed mood, lost or diminution of pleasure, sadness, hopelessness, helplessness, inability to feel emotion (emptiness), feelings of failure or inadequacy, lack /dependence, negativity, avoidance of social situations, worthlessness, exaggerated self-criticism, guilt, trouble concentrating, obtunding of cognition, thoughts of death, low self-esteem, lack of perspective on this, hypochondria, change in appetite, weight changes, disturbed sleep patterns (loss or excessive sleep), slow / psychomotor agitation, loss of libido, fatigue, and irritability. The EBADEP-A has a four-point Likert scale, and for each indicator, there are phrases that the subject has to answer how they feel. The scale has 45 items, the score being 0 to 135 , where higher scores indicate greater depressive symptoms. The reliability of the test was $\alpha=0.92$ according with Rash model, and the higher the score, the more depressive symptoms the person has.

- Inventory of Perceived Family Support (IPSF) (Baptista, 2009): the IPSF assesses the perception that the individual has about the received support from family, and it's composed by 42 items in a three-point scale divided into three dimensions, F1consistent affective (21 items), reflecting questions that deal with the expression of affection among family members; Family Adaptation F2 (13 items), which refers to negative feelings and behaviors toward family and Family Autonomy F3 (8 items), which has issues that can signal relationships of trust, freedom and privacy among members. The inventory's total sum resulted in a Cronbach's alpha of 0.93, and the higher the score the better the support that the individual perceives.

- Beck Hopelessness Scale -BHS (Cunha, 2001): BHS was presented by Beck and colleagues as a measure of the pessimism extent or the negative attitudes extent toward the future. Like the BDI, was adapted by Cunha (2001) for the Brazilian version, with a dichotomic scale involving 20 items, consisting in statements that involve cognitions about hopelessness, and the being necessary mark (right) if agree, or (wrong) if disagrees with the item. It should be noted that the instrument shows evidence of validity for the adult Brazilian population. The total score and the sum of the marked items range from 0 to 20 , and the higher the score, the greater the degree of hopelessness. 


\section{Procedures}

Authorized by ethics committee the collection of data, coordinators and professors of the courses, the instruments were used collectively in rooms with approximately 50 students, during on average 35 minutes. The instruments were randomly arranged, in order to control the fatigue effect, however, always with the identification in the first questionnaire, answered in a single application, after signing the consent-IC.

\section{Results}

Data demonstrated that EBADEP-A pontuation range from 0 to $74(M=22.72 ; S D=15.52)$, indicating light depressive symptoms as compared to the normative group, classified without depressive symptoms (0 to 50$)$. For another data analysis, was used the statistical program Statistical Package for Social Sciences-SPSS version 15. In order to indicate evidence of validity based on its relationship with other variables were used the Pearson correlation, and for further analysis, for average comparison was used the Student $t$ test for two variables and ANOVA for three or more variables, adopting a significance level of $p<0.05$. First, correlational analysis was performed, shown in Table 1.

As shown in Table 1, EBADEP-A correlated significantly with all the instruments. Considering BHS and EBADEP- A, it is considered a adequate magnitude correlation (Prieto \& Muñiz, 2000), indicating that these constructs measure concepts related. Regarding EBADEP- A-A and IPSF, including the sum of all sizes, called Total IPSF, their correlations were negative and these magnitude were low (Sisto, 2007). As for BHS with
IPSF, the correlations also were negative, with low magnitude (Sisto, 2007), suggesting that increased hopelessness implies a lower perception of family support received.

A linear regression analysis was done to determine how depressive symptoms may be influenced by the level of hopelessness and perception of family support, considering depression as dependent variable. A significant result with EBADEP- A and BHS $(t=3.71 ; p=0.001)$ was found, suggesting that hopelessness can be predicted depression symptoms $(\beta=0.26)$, in an equation that explains $0.68 \%\left(r^{2}=6.8 \%\right)$ of the variance. Regarding to IPSF and its factors, were not found associations, indicating that perception of family support cannot predict the number of depressive symptoms presented.

About the socio-demographic variables, there was a mean difference related to gender in EBADEPA scores, where women $(M=15.44)$ had higher scores than men $(M=14.53)(t=2.7, p=0.007)$, suggesting a greater tendency to depression in this gender. Sequentially, were analyzed the variables of age and marital status by ANOVA, showing that there were no significant differences in any of the instruments. However, considering that most participants were single, perhaps the difference could be greater if there were other distribution on this variable.

The family's chef variable education was also analyzed, in which it was founded that the higher education of household head, the greater is the perception of family support received. The differences were significant $(F=4.54, p=0.002)$, and the Tukey test indicated that individuals with illiterate parents with the Incomplete Elementary ( $M$ $=58.74$ ) had lower averages than those with com-

TABLE 1

Pearson Correlation between EBADEP-A with Dimensions of IPSF and Hopelessness Scale

\begin{tabular}{llllll}
\hline & IPSF Consistent affective & IPSF Family adaptation & IPSF Family Autonomy & IPSF Total & BHS \\
\hline BHS & $-0.25(* *)$ & $-0.33(* *)$ & $-0.28(* *)$ & $-0.33(* *)$ & 1 \\
EBADEP- A & $-0.38(* *)$ & $-0.31(* *)$ & $-0.27(* *)$ & $-0.39(* *)$ & $0.42(* *)$ \\
\hline
\end{tabular}

** Correlation at 0.01 (2 tailed).

Source: Own work. 
plete High School or Complete Undergraduate (M $=67.6)$ in the Total dimension. On the Affective consistent $(F=4.99 ; p=0.001)$ and Autonomy $(F=4.16, p=0.003)$ was notice the same result. Thus, the instrument captured the differences that indicated that the increase of the father's education was related to better perception of family support received. In addition, the same analysis was realized with other dimensions of the IPSF, and as the EBADEP-A and BHS, there were no significant differences.

About social economic status, who and how many people live with were not detected significant differences between the variables, then, they are no relation with depression symptoms, hopeless or participants' family support perception in this sample. Related to parents marital state, was verified significance only on consistent affect dimension. ( $F=$ $2.66 ; p=0.035)$, indicating that participants whose parents still married $(M=29.1)$ had a high average in this factor than those who indicate parents widowers $(M=25.29)$ or separate $(M=25.24)$, and with the lowest average the ones whose parents are single $(M=23.78)$.

\section{Discussion}

The literature has consistently pointed the relationship between depressive symptoms, hopelessness and perceived family support (Elmaci, 2006; Estramiana et al., 2010; Lincoln et al., 2005; Monjica et al., 2009; among others). In this sense, this work was one more indicative of the relationship among the constructs and mainly denoted Evidence of validity Based on Relations to Other to EBADEP- A. The results of the correlations made between the IPSF with EBADEP-A were low (Sisto, 2007) and the strength of correlation seems show a direction and magnitude of expected correlation. Thus, these results confirm other data on literature, demonstrating that the increase of depressive symptoms is related to a decreased perception of family support and underline the importance of family support for individual's mental health. (Lincoln et al., 2005; Montoya et al., 2003; Monjica et al., 2009; Sun \& Hui, 2007).
Another point to consider another important point is that the sample did not reported any mental disorder diagnosed, so, this results are expected. As pointed out by Fisher (2010), Meites, Deveney, Steele, Holmes, and Pizzagalli (2008), Montoya et al. (2003) and Monjica et al. (2009), the selfassessment, assessment about other people and about the situations are less negative in people with any mental disorder diagnosed, then, the person evaluate the condition more positively and has more means to deal with adversities. Moreover, despite of few people in these sample present significant depressive and hopeless scores, it was also found significant correlations with depressive symptoms, as showed in this study by correlation, indicating a adequate correlation (Prieto \& Muñiz, 2000), and by regression analyses, showing that depression symptomns can be influenced by hopelessness.

Authors like Abramson et al. (1989), Alford et al. (1995), Alloy et al. (1999) and Panzarella et al. (2006) had already found associations among these constructs where was reported hopelessness as a potential factor for triggering of depression. Tovar, Ríos, Díaz, León, and Vereau (2006) in their study found a correlation with the BDI and BHS of 0.46 whereas in the current study, we obtained a correlation with the BHS EBADEP-A was 0.42 . These results, considering the differences in sample and instruments, have indicated promising results in terms of psychometric quality of the descryptors that measure depressive symptoms (EBADEP-A). According with Beck et al. (1982) the way people interpret events influence the development of mental disorders, and the present study confirm this hyphotesis, dispite the small sample size and the lack of several levels of hopelessness or depression.

The relationship between depressive symptoms and gender showed that women had more depressive symptoms than men are satisfied, since the differences between genders in terms of depressive symptomatology are an established factor in the literature. Among the explanations for these scores, it is important to note that the difference in rates of depression between the genders is commonly found during the reproductive 
period of women, between the adolescent and adult life. However, when observed in childhood or in older adults, depression has a similar prevalence between the genders. (APA, 2002). Some factors that justify the prevalence rate of major depression in women on adolescence, are hormonal changes, altered levels of gamma-aminobutyric acid (GABA), noradrenaline and serotonin, which cause changes in mood, more "rumination", that implied on a greater concern about the problem repeatedly, great concern with appearance, and greater attention to relationships as a source of emotional support than adolescents of the opposite gender, which tend to externalize their problems (Justo \& Calil, 2006; Li et al., 2006).

Regarding age, no mean differences were found. Probably, this result can be given because of the variance in this variable was small, besides the small sample size (Prieto \& Muñiz, 2000). Still, marital status was unrelated to the variables, this result can be attributed to high concentration of single participants, and also an age group with little variation. These results thus do not confirm other studies, such as Barreira, Cavaglia, and Pires (2001) that found marital status related with more anticipatory cognitions and depression, that is, be male and single increase the tendency of depressive symptoms, as well as point on Santos and Kassouf (2006), in which the marriage was a protective factor for depressive symptoms. Once on WHO (2006) data, separate people, legally or not, have higher risks, while single or married, less risk, indicating the differences on this variable in the literature.

Among other results, it was found that the more education the family's cheaf, the greater the family support received by the individual. Most parents' education can imply a longer time in relationships, greater discrimination of affective states and more efficient communication, necessary elements for the individual's best cognitive development. As for socioeconomic status, it was not correlate with the other variables, unlike the study of Lincoln et al. (2005), which has found relationships between social support and low economic status.
Furthermore, the perception of family support, depression and hopelessness do not depends on the number of people and who lived with the person suggesting that well-established social relationships act like a factor in regardless of the number and family composition. In the sample, the parents' marital status interfered with the individual's perception about the reactions of affection and consistency, as well as family support a total dimension that refers to research of Elmaci (2006), what showed that adolescents whose parents had been separated indicated a higher level of depression and lower family adaptation than those who were from entire families, as in the Osnaya and Pérez (2010), in which live with one parent or other family members, such as passing through some difficult family appeared as a risk factor for developing mental disorders and suicide risk in the sample, remembering that both overprotection and lack of family support act as factors that predispose individuals to depressive symptoms (Baptista, 2009).

Lastly, it should be noted that the results presented in this research can be considered promising for the Depression Scale-EBADEP- A, once that the correlations in strength and magnitude with the IPSF corroborated with national and international literature, regarding the magnitude and significance between hopelessness and depression, the results also were expected, demonstrating the relationship of these constructs, in a similar manner, the scale also was able to make discrimination with regard to gender, one of the most pronounced in relation the prevalence of depressive symptoms.

Finally, it's necessary to emphasize the need of studies in the context of psychometrics, considering that psychological tests not only produced and marketed in Brazil but in many countries, have an acceptable psychometric properties and be reliable. The construction of tests is an important goal to be achieved, however, only the efforts related to a constant update and research by professional in the field of psychological assessment could offer it, considering the influence of cultural and language embedded in this process. 


\section{References}

Abramson, L. Y., Alloy, L. B., \& Metalsky, G. I. (1989). Hopelessness depression: A theory- based subtype of depression. Psychological Review, 96(2), 358-372.

Alford, B. A., Lester, J. M., Patel, J. P., \& Giunta, L. C. (1995). Hopelessness predicts future depressive symptoms: A prospective analysis of cognitive vulnerability and cognitive content specificity. Journal of Clinical Psychology, 51(3), 331-339.

Alloy, L. B., Abrahamson, L. Y., \& Francis, E. L. (1999). Do negative cognitive styles confer vulnerability to depression? Current Directions in Psychological Science, 8(4), 128-132.

American Psychiatric Association (2002). Manual diagnóstico e estatístico de transtornos mentais (4a. ed. rev., C. Dornelles, Trad.). Porto Alegre: Artmed.

Associação Nacional de Empresas de Pesquisa (2000). Critério de classificação econômica brasil. Retrieved 29 August, 2007, from www.anep.org.br

Baptista, M. N. (2007). Inventário de Percepção de Suporte Familiar (IPSF): estudo componencial em duas configurações. Psicologia: Ciência e Profissão, 27(3), 496-509.

Baptista, M. N. (2009). Inventário de Percepção de Suporte Familiar. Livro de Instruções. São Paulo: Vetor.

Baptista, M. N. (2012). Escala Baptista de Depressão versão Adulto- EBADEP-A. São Paulo: Vetor.

Barreira, D. P., Cavaglia, F., \& Pires, A. M. (2001). Cognições antecipatórias: um estudo comparativo e correlacional. Psicologia, Saúde e Doenças, 2(1), 101-105.

Beck, T. A., Rush, J. A., Shaw, F. B., \& Emery, G. (1982). Terapia cognitiva da depressão. Rio de Janeiro: Zahar.

Cunha, J. A. (2001). Manual da versão em portugês das Escalas Beck. São Paulo: Casa do Psicólogo.

Elmaci, F. (2006). The role of social support on depression and adjustment levels of adolescents having broken and unbroken families. Educational Sciences: Theory \& Practice, 6(2), 421-431.

Estramiana, J. L. A., Luque, A. G., \& Gallo, I. S. (2010). Causas sociales de la depresión. Revista Internacional de Sociología, 68(2), 333-348.

Fester, C. B. (1983). Functional analysis of depression. American Psychologist, 23(10), 857-870.
Fisher, L. B. (2010). Positive cognitions and their role in depression, hopelessness and suicidal ideation. Dissertação de mestrado, Case Western Reserve University, Cleveland, Ohio, United States. Retrieved 05 Mai, 2011, from http://etd.ohiolink.edu/view. cgi?acc num $=$ case 1258156356

Herring, M., \& Kaslow, N. J. (2002). Depression and attachment in families: A child-focused perspective. Family Process, 41(3), 494-518.

Justo, L. P., \& Calil, H. M. (2006). Depressão- o mesmo acometimento para homens e mulheres? Revista de Psiquiatria Clínica, 33(2), 74-79.

Kaplan, H. I., Sadock, B. I., \& Grebb, J. A. (2007). Compêndio de psiquiatria: ciência do comportamento e psiquiatria clínica (9th. ed., D. Batista, Trad.). Porto Alegre: Artmed.

Kornstein, S. G. (1997). Gender differences in depression: Implications for treatment. Journal of Clinical Psychiatry, 58(Suppl. 15), 12-18.

Li, C. E., DiGiuseppe, R., \& Froh, J. (2006). The roles of gender, gender and coping in adolescent depression. Adolescence, 41(163), 409-415.

Lincoln, K. D., Chatters, L. M., \& Taylor, R. J. (2005). Social support, traumatic events, and depressive symptoms among African Americans. Journal of Marriage and Family, 67(3), 754-766.

Lopes, P., Barreira, D. P., \& Pires, A. M. (2001). Tentativa de suicídio na adolescência: avaliação do efeito de gênero na depressão e personalidade. Psicologia, Saúde e Doenças, 2(1), 47-57.

Meites, T. M., Deveney, C. M., Steele, K. T., Holmes, A. J., \& Pizzagalli, D. A. (2008). Implicit depression and hopelessness in remitted depressed individuals. Behaviour Research and Therapy, 46(9), 1078-1084.

Monjica, C. A., Sáenz, D. A., \& Rey-Anacona, C. A. (2009). Riesgo suicida, desesperanza y depresión en internos de un establecimiento carcelario colombiano. Revista Colombiana de Psiquiatría, 38(4), 681-692.

Montoya, R. Q., Jiménez, L. P., Villavicencio, M. E. F., La Rosa, A. C. de, \& Abundiz, S. V. (2003). Desesperanza y tentativa suicida [On Line]. Investigación en Salud, 5(2). Available atwww.invsalud@cucs. udg.mx 
Oliveira, M. G., Fonseca, P. P., \& Del Porto, J. A. (2002). Versão brasileira da entrevista de Paykel para eventos de vida recentes. Revista Brasileira de Terapia Cognitivo-Comportamental, 4(1), 47-71.

Osnaya, M. C., \& Pérez, J. C. R. (2010). La desesperanza de riesgo em jóvenes mexicanos y aspectos sociodemográficos asociados: diferencias por sexo. Psicologia y Salud, 20(2), 195-201.

Osnaya, M. C., Pérez, J. C. R., \& Romo, L. de L. E. (2005). La didática constructiva de una escala de desesperanza: resultados preliminares. Investigación en Psicología, 10(2), 311-324.

Organização Mundial da Saúde. (1993). Classificação dos transtornos mentais e do comportamento - CID10: descrições e diretreizes diagnósticas (C. Dorgival, Trad., Vol. 3, 10th ed.). Porto Alegre: Artes Médicas.

Page, R. M., Yanagishita, J., Suwanteerangkul, J., Zarco, E. P., Mei-Lee, C., \& Miao, N. F. (2006). Hopelessness and loneliness among suicide attempters in school- based samples of Taiwanese, Philippine and Thai adolescents. School Psychology International, 27(5), 583-598.

Panzarella, C., Alloy, L. B., \& Whitehouse, W. G. (2006). Expanded hopelessness theory of depression: On the mechanisms by which social support protects against depression. Cognitive Therapy and Research, 30(3), 307-333.

Peñate, W., Perestelo, L., Bethencourt, J. M., \& Ramírez, G. (2009). La predicción del nivel de depresión por variables cognitivas, conductuales y temperamentales en un intervalo de seis meses. Psicothema, 21(3), 341-346.

Prieto, G., \& Muniz, J. (2000). Um modelo para evaluar la calidad de tests usados na Espanha. Papeles del
Psicólogo, 77, 65-71. Retrieved March, 25th 2008, from http://www.cop.es/vernumero.asp?id=41

Sander, J. B. (2004). Investigación en adolescência: tópicos y tendências contemporáneas. Revista Latinoamericana de Psicología, 36(3), 383-389.

Santos, M. J., \& Kassouf, A. L. (2006). Uma estimativa econométrica do retorno da educação para a saúde mental dos brasileiros: escolaridade versus depressão [On line]. Retrieved 18th Mai, 2008, from http:// www.cepea.esalq.usp.br/pdf/educacao depressao. pdf

Sisto, F. F. (2007). Delineamento correlacional. In M. N. Baptista \& D. C. Campos (Orgs.), Metodologias de pesquisa em ciências: análise quantitativa e qualitativa (pp. 90-101). Rio de Janeiro: LTC.

Stafford, S. M., Alloy, L. B., Abramson, L. Y., \& Crossfield, A. G. (2006). Negative cognitive style as a predictor of negative life events in depressionprone individuals: A test of the stress generation hypothesis. Journal of Affective Disorders, 99(13), $147-154$.

Sun, R. C. F., \& Hui, E. K. P. (2007). Building social support for adolescents with suicidal ideation: Implications for school guidance and counseling. British Journal of Guidance and Counseling, 35(3), 299-316.

Tovar, J. A., Ríos, L. R. L., Díaz, C. P., León, A. F., \& Vereau, J. E. (2006). Escala de Desesperanza de Beck (BHS): adaptación y características psicométricas. Revista IIPSI, 9(1), 69-79.

World Health Organization. (2000). WHO initiative on depression in public health [On Line]. Retrieved 30th April, 2008 from http://www.who.int

World Health Organization (2006). Conquering depression. Mental health and substance abuse [On line]. Retrieved 10th April, 2008 from http://www.searo. who.int 